\title{
SYMPOSIUM ON TREATY EXIT AT THE INTERFACE OF DOMESTIC AND INTERNATIONAL LAW
}

\section{TREATY EXIT AND LATIN AMERICA'S CONSTITUTIONAL COURTS}

\author{
Alexandra Huneeus* and René Urueña ${ }^{\dagger}$
}

Constitutional courts in Latin America have used judicial review to enhance the relevance of international law in recent years. Some scholars even speak of a growing "constitutionalization of international law" in the region. ${ }^{1}$ But these domestic courts can also act as gatekeepers that blunt or entirely deflect the domestic impact of international law. This essay explores three recent episodes in which constitutional courts joined or led efforts to escape treaty obligations: the Venezuelan Supreme Court's judgment urging the Chávez Administration to denounce the American Convention of Human Rights on constitutional grounds, which Chavez then did in 2012 (a courtinspired treaty exit); the Colombian executive's 2013 petition to have Colombia's acceptance of the International Court of Justice's (ICJ's) jurisdiction under the Pact of Bogotá declared unconstitutional (a courtlegitimated treaty exit); and the Dominican Republic (DR) Constitutional Tribunal's 2014 judgment holding that the DR's acceptance of the jurisdiction of the Inter-American Court of Human Rights (IACtHR) had been unconstitutional (a court-led treaty exit).

Each of the domestic rulings to be discussed was issued in response to an adverse judgment from an international court, and each reflects an effort to quell the international court's impact by attacking the instrument granting jurisdiction to the court. The essay describes the episodes in context, and then analyzes them as a single phenomenon. Taken together, the cases show that in the realm of treaty exit the region's constitutional courts are drawing on constitutional law to take on a surprisingly prominent foreign affairs role.

\section{A Court-Inspired Treaty Exit}

In 2008, the IACtHR ruled that Venezuela had violated the American Convention on Human Rights when it removed three judges from the bench. Never shy of injunctive relief, the IACtHR ordered Venezuela to reinstate the three judges - a direct countermand to the Venezuelan Supreme Court decision to remove them. The IACtHR also held that President Hugo Chávez's system for ostensibly cleaning the judiciary of corruption violated the American Convention by rendering all judges temporary, and thereby eliminating their independence. The political backdrop to this case was Chávez's Bolivarian Revolution, through which he promised to transform Venezuelan society and rid all government institutions of entrenched corruption. The IACtHR judgment thus threatened a key executive program.

* Associate Professor, University of Wisconsin.

+ Associate Professor, Universidad de Los Andes (Colombia).

${ }^{1}$ Alexandra Huneeus, Introduction to Symposium on the Constitutionalization of International Law in Latin America, 109 AJIL UNBOUND 89 (2015).

\footnotetext{
The American Society of International Law, Alexandra Huneeus and René Urueña $@ 2018$. This is an Open Access article, distributed under the terms of the Creative Commons Attribution licence (http://creativecommons.org/licenses/by/4.0/), which permits unrestricted re-use, distribution, and reproduction in any medium, provided the original work is properly cited.
} 
The Venezuelan Supreme Court was displeased. It responded by ruling that the IACtHR judgment usurped the Venezuelan court's functions, in contradiction to both the Venezuelan Constitution and the American Convention. To bring the point home, the Supreme Court took an unusual tack. It concluded the opinion by ruling that the international judgment could not be implemented, and, more trenchantly, by issuing a plea to the executive to denounce the American Convention, "in light of the clear usurpation of functions in which the Inter-American Court of Human Rights has incurred."

The plea fell on sympathetic ears. Upon first assuming the presidency, Chávez had looked favorably on the Inter-American Human Rights system. But as the international reports and judgments criticizing his policies began to emerge- at what he claimed was an unprecedented pace-Chávez started to publicly condemn the system as biased and overweening. In 2012, he finally denounced the American Convention in a letter that makes frequent reference to the Supreme Court's judgment, and in particular to its holding that the IACtHR's judgments contradicted constitutional law. ${ }^{3}$

Venezuela's exit has had important repercussions. Analysts in the region have warned of a "domino effect" of withdrawals, particularly by Bolivia, Nicaragua, and Ecuador. ${ }^{4}$ That risk has kept the Inter-American Court and Commission on unstable ground. It has also meant that the Inter-American System has played a minimal role in one of the most pressing issues facing the region: the political crisis in Venezuela.

One issue that may reemerge in the future is whether the denunciation was unconstitutional. In September 2012, a group of lawyers and scholars filed a challenge before the Venezuelan Supreme Court. ${ }^{5}$ The 1999 Venezuela Constitution expressly mentions the American Convention and incorporates human rights treaties at a supralegislative level as part of a constitutional block. Denunciation of the American Convention, this suit claims, can therefore only take place via constitutional amendment. It may be that Venezuela's denunciation, which is permissible under international law, is invalid in domestic law. The Supreme Court has yet to issue a response.

\section{A Court-Legitimated Treaty Exit}

If in Venezuela the high court pled for the executive to exit a treaty, in Colombia it was the executive that sought help from the courts.

Since 2001, Nicaragua and Colombia had been litigating before the ICJ a dispute concerning territorial limits in the Caribbean Sea. In November 2012, the ICJ rendered its judgment, rejecting most of Colombia's claims. ${ }^{6}$ This decision was perceived in Colombia as an unmitigated defeat, and Colombians blamed their President, whose favorability fell 15 percent in the week after the decision. ${ }^{7}$ Politically cornered, and lacking any other real options that would appease an outraged public, President Santos decided to denounce the Pact of Bogotá, a treaty that gives the ICJ jurisdiction over legal disputes between Latin American states.

Exiting served two purposes. After the ICJ judgment, Nicaragua had signaled that it would sue Colombia again, this time over a separate continental shelf dispute. The first objective of Colombia's withdrawal was, therefore, to

\footnotetext{
2 Tribunal Supremo de Justicia de Venezuela (Sala Constitucional), Sentencia n 1939 del 18 de Diciembre de 2008 (Exp. 08-1572).

${ }^{3}$ Letter from Nicolás Maduro, Venezuelan Foreign Minister, to José Miguel Insulza, OAS Secretary General (Sept. 6, 2012) (on file with author).

${ }^{4}$ Temen "efecto dominó" tras salida de Venezuela de la Convención Americana, El Universal (Sept. 14, 2013) (Venez.).

${ }^{5}$ Marino Alvarado Betancourt et al., Acción Popular de Nulidad por Inconstitucionalidad contra la Denuncia de la Convención Americana sobre Derechos Humanos (Sept. 27, 2012).

${ }^{6}$ Territorial and Maritime Dispute (Nicar. v. Colom.), 2012 ICJ Rer. 624 (Nov.19).

${ }^{7}$ Baja favorabilidad de Santos por fallo de La Haya, Caracol Radio (Nov. 28, 2012) (Colom.).
} 
prevent Nicaragua from filing additional ICJ claims. But this gambit failed: in 2016, the ICJ claimed jurisdiction over the new Nicaragua v. Colombia case as it fell within the period of notification of treaty withdrawal. ${ }^{8}$

The second objective was political: the President needed to respond to the domestic fallout of the defeat. But even as the denunciation played well politically, Colombia was still bound by the ICJ judgment, which was issued prior to the denunciation. Something else was needed to find a legally plausible basis for noncompliance.

Enter thus the Colombian Constitutional Court. President Santos filed a suit claiming that the congressional act that had approved the Pact of Bogotá was unconstitutional. Article 101 of the 1991 Colombian Constitution allows territorial borders to be modified only by a treaty or an arbitral award—and not, the President argued, in response to an international judicial decision. ${ }^{9}$ With this lawsuit, the government hoped to create a new fact on the ground: a domestic ruling making it impossible for Colombia to comply with the ICJ decision without violating its own Constitution. To be sure, this argument is impermissible under international law-but, as in the DR case (discussed below), that was not the point. The President's goal was to mobilize a famously independent domestic court to create a space to avoid compliance with an unpopular international ruling.

The Constitutional Court did not outright declare the law accepting the Pact unconstitutional, but it nonetheless gave the government what it needed. It held that ICJ decisions that modify territorial borders must be incorporated into domestic law through a treaty. ${ }^{10}$ The Court seemingly went out of its way to make things easy for the executive. For example, one way to reconcile Colombia's duties under both international and constitutional law would have been to order the government to negotiate a treaty with Nicaragua that both implemented the ICJ decision and complied with Article 101 of the Constitution. Such a decision would have been in line with prior ambitious structural orders by the Colombian Constitutional Court. Instead, the Court left open the question of what the government needed to do, which was exactly the kind of ruling the President was hoping for. Ultimately, even if internal law is not a justification for noncompliance with ICJ decisions, the Constitutional Court judgment allowed the government to avoid the appearance of openly flouting international law, and helped legitimate the exit decision. The government was quick to cite the judgment in response to the new ICJ application filed by Nicaragua:

The decision of the highest judicial organ in Colombia, entrusted with the interpretation of the Constitution, shows that Colombia is not a State whose policy is one of non-compliance with its international obligations. The requirement that an international judgment must be implemented by means of a treaty is a product of the constitutional relationship between international and national law in a dualist system. It is indicative of compliance, not non-compliance-as Nicaragua seeks to argue. ${ }^{11}$

\section{A Court-Led Treaty Exit?}

In Venezuela and Colombia, high courts helped sow the ground for a successful treaty exit, but the ultimate decision still rested with the executive. In the DR, the constitutional court's role was more prominent still.

In August 2014, the IACtHR issued a ruling condemning the DR's treatment of persons of Haitian descent or nationality, and impugning in particular a 2013 domestic court decision that threatened to strip hundreds of

\footnotetext{
${ }^{8}$ Question of the Delimitation of the Continental Shelf Between Nicaragua and Colombia Beyond 200 Nautical Miles from the Nicaraguan Coast (Nicar. v. Colom.), Preliminary Objections, 2016 ICJ Rer. 100 (Mar. 17).

${ }^{9}$ The Pact of Bogota was ratified before the 1991 Constitution. The Colombian Constitutional Court has held that constitutionality of treaties is to be assessed under the Constitution in force at the moment of the decision. See Corte Constitucional [C.C.] [Constitutional Court], agosto 10, 1998, Sentencia C-400/98 (Colom.).

${ }^{10}$ C.C., mayo 2, 2014, Sentencia C-269/14 (Colom.).

${ }^{11}$ Alleged Violations of Sovereign Rights and Maritime Spaces in the Caribbean Sea (Nicar. v. Colom.), Preliminary Objections of the Republic of Colombia vol. I, para 2.46 (Dec. 19, 2014).
} 
Dominican nationals of their citizenship. The IACtHR faced an immediate backlash: the President announced that he rejected the "biased and inopportune" judgment and would not comply. ${ }^{12}$

Three months later, the Constitutional Tribunal of the DR declared that the state was not subject to the jurisdiction of the IACtHR, and perhaps had never been. The Tribunal held that the instrument by which the DR had seemingly accepted the IACtHR's jurisdiction in 1999 was constitutionally invalid: it was the product of a sole executive act, whereas the Constitution requires a congressional vote on treaty commitments. ${ }^{13}$ It did not matter, the Tribunal said, that in the interim the IACtHR had issued several contentious judgments and numerous provisional measures against the DR; that the Tribunal itself had held in earlier opinions that the IACtHR's judgments were directly binding; that Congress had enacted legislation requiring that the Tribunal consider IACtHR jurisprudence; or even that a Dominican judge had served on the IACtHR. ${ }^{14}$

With this audacious move, the Constitutional Tribunal engaged in what might be called a court-led treaty exit. Or at least it attempted to do so. Most legal scholars, along with the Inter-American Court and Commission, argue that the DR remains under the IACtHR's jurisdiction. In the first place, the instrument accepting jurisdiction was not a self-standing treaty obligation, but one derived from the American Convention, which Congress approved in 1978. Further, even if the instrument was deemed to be a self-standing treaty, it would be binding on the DR. Under the Vienna Convention on the Law of Treaties, the DR may not use internal law to excuse noncompliance; and even if there had been a violation of internal law relating to treaty-making, it was not one that could be classified as "manifest." 15

Strong though they are, these international law arguments may be inapposite. The problem is that the DR Tribunal is the ultimate judicial authority on domestic law, including foreign affairs law. The case thus opens a breach between international and domestic law; it may even be that compliance with one body of law means noncompliance with the other. The IACtHR previously had held that a state cannot revoke the instrument recognizing its jurisdiction. This interpretation would prevent the DR from formally exiting the IACtHR's authority in compliance with the Constitutional Tribunal's ruling unless it denounces the American Convention entirely.

The DR judgment has profound implications for the Inter-American System. All Latin American states are, like the DR, presidential democracies in which the executive plays a singular role in foreign relations. In addition, most constitutions in the region stipulate that treaties are made by the president subject to congressional approval. Of the twenty-two states that have accepted the IACtHR's jurisdiction, only two did so upon ratification; the remainder accepted the Court's jurisdiction at a later date through a sole executive act. In each of these states, litigants could try to raise the argument that separate congressional approval was required.

Thus far, the DR Tribunal's argument has received surprisingly little commentary from scholars, lawyers, or even the Inter-American System itself. The IACtHR has issued provisional measures against the DR in two cases, but it has not issued compliance reports or called for compliance hearings in its judgments against the state. In addition, the Inter-American Commission's 2016 report on the DR made no mention of the 2014 judgment. For now, in other words, the Inter-American System is mostly ignoring the DR Tribunal, and is being ignored in turn. Significantly, the DR has not denounced the American Convention.

\footnotetext{
12 Presidencia República Dominicana, El Gobierno dominicano rechaza la sentencia de la Corte Interamericana de Derechos Humanos (Oct. 23, 2014).

13 Tribunal Constitucional de la República Dominicana, Sentencia TC/0256/14 (2014).

${ }^{14}$ Dinah Shelton \& Alexandra Huneeus, In re Direct Action of Unconstitutionality Initiated Against the Declaration of Acceptance of the Jurisdiction of the Inter-American Court of Human Rights, 109 AJIL 866 (2015).

${ }^{15}$ Vienna Convention on the Law of Treaties arts. 27 and 46(2), May 23, 1969, 1155 UNTS 331.
} 
The three judicial interventions share important features. First, an international court issued a judgment against the state on a highly contentious matter that inflamed nationalist sentiment. Second, the executive sought to evade implementation of the order. Third, a constitutional court came to the rescue, providing the executive with an escape route via constitutional law.

At first, it might seem puzzling that the powerful Colombian Constitutional Court would defer to the executive at all. The story in that country is rather one of domestic courts using international law to carve out a space of judicial autonomy, and of amplifying the role of international law in the domestic sphere. On closer look, however, all three cases may be examples of domestic courts using judicial review to protect their positions vis-à-vis their international colleagues. In each case, the international court had issued a judgment that either directly reprimanded the domestic court (as in Venezuela and the DR), or which injured nationalist sentiment (for example, by limiting the power of the state to control its borders, as in the Colombian and DR cases). In each, therefore, we can imagine that the domestic court collaborated with the executive not (or at least not only) due to executive pressure, but because it had its own institutional reasons to defy the international court.

Ultimately, these three cases reveal that there is a new actor in the realm of foreign affairs and treaty exit in the region: high courts, armed with judicial review and a quickly evolving body of constitutional law. While none of the three constitutions discussed required judicial approval for treaty exit, in all three cases the executive was assisted by a domestic high court. The main loser here is the legislative branch. Constitutional design in Latin America has traditionally tasked legislatures with the democratic control of treaty-making power, ${ }^{16}$ but Congress was a bystander in all three cases: it was either the indirect beneficiary of an empowered constitutional court (as was the case in the DR), or simply absent from the debate (as in Venezuela and Colombia).

The cases also serve to remind us of law's double edge. Scholars have argued that the constitutional dialogue among Latin America's courts has ushered in an era of shared "transformative constitutionalism" focused on equality, democracy, and human rights. ${ }^{17}$ The treaty-exit cases show that it is also being wielded to support illiberal or nationalist political agendas hostile to international institutions.

Finally, the cases suggest not only that scholars concerned with treaty exit should look to Latin America, where presidential systems abound, but also that in the new world of international and constitutional courts, there are a wealth of novel legal issues around treaty exit. For example, the judicial procedure that ultimately led to treaty exit in Colombia engaged a wide set of participants, including civil society. Similarly, it was private citizens that filed the constitutional challenge to the IACtHR's jurisdiction in the DR, as well as the constitutional challenge to Venezuela's denunciation. Such broad participation is often the case with complex constitutional adjudication in Latin America. ${ }^{18}$ How does this process affect treaty exit? Further, what is the constitutional status of an instrument accepting court jurisdiction pursuant to a preexisting treaty, and what is the constitutional status of an international court order? How, if at all, will national congresses push back on executives seeking exit emboldened by constitutional courts? Finally, in light of the constitutional block doctrine, when does an exit from a human rights treaty require a prior constitutional amendment?

16 Darío Villarroel, Derecho de los Tratados en las Constituciones de América 171-220 (2014).

17 Armin von Bogdandy et al., Transformative Constitutionalism in Latin America: The Emergence of a New Ius Commune (2017).

${ }^{18}$ Roberto Gargarella, "We the People" Outside of the Constitution: The Dialogic Model of Constitutionalism and the System of Checks and Balances, 67 Current Legal Probs. 1 (2014). 